\title{
PENGARUH SUBSTITUSI BUAH SUKUN (ARTOCARPUS COMMUNIS) DAN KACANG HIJAU (VIGNA RADIATA) TERHADAP DAYA TERIMA DAN KANDUNGAN PROTEIN FLAKES
}

\author{
Alzha Adila Harisina ${ }^{1}$, Annis Catur Adi ${ }^{2}$, Farapti ${ }^{2}$ \\ ${ }^{1}$ Program Studi S1 Ilmu Gizi, Fakultas Kesehatan Masyarakat, Universitas Airlangga, Surabaya \\ ${ }^{2}$ Departemen Gizi Kesehatan, Fakultas Kesehatan Masyarakat, Universitas Airlangga, Surabaya \\ Email: adilaalzha@gmail.com
}

\begin{abstract}
ABSTRAK
Buah sukun merupakan bahan makanan pokok alternatif sumber karbohidrat dan kacang hijau sebagai sumber protein nabati yang berpotensi diolah menjadi flakes sebagai alternatif produk PMT-AS. Penelitian ini bertujuan untuk mengetahui pengaruh substitusi buah sukun dan kacang hijau terhadap daya terima dan kadar protein serta menentukan formula terbaik untuk menghasilkan flakes berkualitas. Jenis penelitian adalah eksperimental murni dengan desain rancangan acak lengkap (RAL) 3 kali pengulangan. Panelis tidak terlatih yang digunakan adalah 34 siswa kelas 2 sekolah dasar. Hasil uji daya terima yang paling disukai panelis adalah flakes F1 (sukun 50 g, kacang hijau $50 \mathrm{~g}$ dan tepung tapioka $50 \mathrm{~g}$ ) memiliki nilai mean rank tertinggi pada karakteristik aroma $(87,00)$, tektur $(95,00)$ dan rasa $(89,50)$, sedangkan warna memiliki nilai mean rank $(77,5)$ di bawah warna formula dasar $(83,5)$. F1 memiliki kandungan protein per penyajian adalah $9,8 \mathrm{~g}$. Analisis statistik perbedaan daya terima menggunakan uji chi square pada penilaian warna, aroma, tekstur, dan rasa didapatkan hasil terdapat perbedaan yang signifikan $(\alpha \leq 0,05)$ pada setiap karakteristik antara F0 dengan F2, F0 dengan F3, F1 dengan F2 dan F1 dengan F3, sedangkan tidak terdapat perbedaan yang signifikan $(\alpha \geq 0,05)$ terhadap daya terima warna, aroma, tekstur dan rasa flakes F0 dengan F1 dan F2 dengan F3. Formula optimasi ditinjau dari komposisi terbaik, daya terima dan kandungan gizi adalah F1 (sukun $50 \mathrm{~g}$, kacang hijau $50 \mathrm{~g}$ dan tapioka $50 \mathrm{~g}$ ) dapat dijadikan alternatif produk PMT-AS.
\end{abstract}

Kata kunci: buah sukun, daya terima, flakes, kacang hijau, protein

\begin{abstract}
Breadfruit is staple food of carbohydrate source alternative, while the mung beans is source of vegetable protein that potential to be processed as flakes for supplementary feeding of schoolchild. This research aims to determine the effect of breadfruit and mung beans substitution toward the acceptance and protein content, as well as determine the best formula to produce a quality flakes. Type of research is true experimental design with completely randomized design with 3 times replicating. Untrained panelists were used $342^{\text {nd }}$ elementary school students. Product acceptance was tested using statistical analysis Chi square $(\alpha \leq 0.005)$. The result of product acceptance test shown the most preferred panelist is flakes F1 (breadfruit 50g, mung beans $50 \mathrm{~g}$, and tapioca flour $50 \mathrm{~g}$ ) which have mean value of the highest rank in the aroma characteristic (87.00), texture (95.00) and taste (89.50), while the color values mean rank (77.5) under the color of the basic formula (83.5). F1 has $9.8 \mathrm{~g}$ protein content per serving. Statistical analysis of acceptance differences using chi square test on the assessment of the color, aroma, texture and flavor showed significant differences $(\alpha \leq 0.05)$ on each characteristic between F0 to F2, F0 to F3, F1 with F2 and F1 to F3, whereas there was no significant difference $(\alpha \geq 0.05)$ for the acceptance of color, aroma, texture and flavor flakes F0 to F1 and F2 to F3. The best composition, acceptability, and nutritional value was found in F1 (breadfruit $50 \mathrm{~g}$, mung beans $50 \mathrm{~g}$, and tapioca flour $50 \mathrm{~g}$ ) and can be used as alternative of supplementary feeding for school students.
\end{abstract}

Keywords: Breadfruit, acceptance, flakes, mung beans, protein

\section{PENDAHULUAN}

Periode usia sekolah khususnya pada anak sekolah dasar merupakan salah satu tahapan siklus manusia yang sangat menentukan kualitas sumber daya manusia (SDM). Kualitas SDM salah satunya dilihat dari prestasi belajar anak. Menurut Syatyawati (2013), terdapat hubungan status gizi pada anak sekolah dasar dengan 
prestasi belajar. Kualitas SDM yang rendah seperti pertumbuhan dan perkembangan intelektual salah satunya diakibatkan masalah gizi yang kurang. Penanggulangan masalah gizi tersebut sangat penting terutama pada periode anak usia sekolah untuk menunjang pertumbuhan dan prestasi belajar anak sehingga diperlukan program yang tepat dalam mengatasi masalah tersebut (WHO, 2006 dalam De Onis, 2011).

Program yang sudah dilakukan untuk mengurangi masalah gizi kurang pada anak sekolah di Indonesia adalah Pemberian Makanan Tambahan Anak Sekolah (PMT-AS). PMT-AS merupakan salah satu strategi untuk memperbaiki keadaan gizi peserta didik. Peraturan Menteri Dalam Negeri Nomor 18 Tahun 2011 menyatakan bahwa PMT AS merupakan kegiatan pemberian makanan pada peserta didik dalam bentuk jajanan atau makanan lengkap dengan memperhatikan aspek mutu bahan dan keamanan pangan. Produk PMT-AS diharapkan mengandung 300 kalori dan 5 gram protein, sehingga dapat menyumbang 15-20\% AKG anak sekolah. Berdasarkan penelitian Marsaoly, dkk. (2011) menunjukkan perbedaan status gizi yang positif sebelum dan sesudah pemberian intervensi (PMT-AS) berupa telur rebus dan bubur kacang hijau pada anak sekolah selama 8 pekan.

Produk PMT-AS dengan kualitas dan kuantitas yang tepat serta siap konsumsi sangat dibutuhkan anak sekolah untuk memenuhi kebutuhan gizi harian. Namun, produk PMT-AS yang ada selama ini masih belum diterima dengan baik oleh anak sekolah dikarenakan kurang menarik baik dari segi penyajian, bentuk, dan rasa. Oleh sebab itu diperlukan inovasi baru untuk menarik perhatian anak sekolah dalam mengonsumsi PMT-AS. Salah satu inovasi dalam mengolah produk PMT-AS berupa snack adalah flakes. Flakes merupakan produk sereal dan siap saji yang memiliki daya terima tinggi pada kalangan masyarakat khususnya anak-anak. Flakes pada umumnya berbahan dasar jagung dan tepung tapioka (Koswara, 2009 dan Widyasitoresmi, 2010). Namun, untuk mendukung program diversifikasi makanan diperlukan pemanfaatan bahan makanan lokal yang tinggi energi dan protein seperti padi-padian, umbi, kacang-kacangan, ikan, sayur dan buah (Kemendagri, 2011).

Buah sukun (Artocarpus communis) merupakan buah yang tinggi akan karbohidrat sebagai sumber energi namun pemanfaatannya sebagai alternatif makanan pokok yang masih belum dimaksimalkan padahal keberadaannya melimpah. Produksi sukun di Indonesia terus meningkat dari 35.435 ton pada tahun 2000 menjadi 92.014 ton pada 2007 (Kemenpan, 2007). Sukun dapat dijadikan sumber pangan pokok alternatif dikarenakan kandungan karbohidratnya yang tinggi $27,88 \%$ per $100 \mathrm{~g}$ buah (Adinugraha, dkk., 2012). Buah sukun mengandung lemak dan protein yang rendah dibandingkan dengan tepung terigu (PERSAGI, 2009). Oleh karena itu, perlu adanya penambahan sumber protein seperti kacang hijau. Kacang hijau juga melimpah keberadaannya dan merupakan sumber protein nabati yang berperan dalam perbaikan gizi. Nilai gizi yang terkandung dalam 100 gram kacang hijau adalah 22,9 g protein, 1,5 g lemak, 56,8 g karbohidrat. Selain protein, kacang hijau juga mengandung zat gizi mikro yang penting untuk pertumbuhan linier dan kepadatan tulang yaitu kalsium $(233 \mathrm{mg} / 100$ g) (PERSAGI, 2009 dan Valentina, dkk., 2014).

Berdasarkan latar belakang di atas, diperlukan penelitian dalam mengetahui pengaruh buah sukun dan kacang hijau serta penentuan komposisi yang tepat sehingga produk flakes dapat diterima, layak dan berkualitas ditinjau dari daya terima dan nilai gizi (protein) sebagai alternatif PMT-AS.

\section{METODE}

Penelitian pada tahap pengembangan formula adalah eksperimental murni (true experimental) dengan desain rancangan acak lengkap (RAL) yaitu variasi formula subtitusi buah sukun dan kacang hijau pada pembuatan flakes dengan tiga kali pengulangan. Penelitian dilakukan pada bulan April-Juni 2016. Pembuatan flakes dilakukan di Laboratorium Gizi Fakultas Kesehatan Masyarakat Universitas Airlangga Surabaya, uji organoleptik dilakukan di MI Unggulan Sabilillah Lamongan dan uji kadar protein di Laboratorium Badan Penelitian dan Konsultasi Industri (BPKI) Surabaya. 
Tabel 1. Formula Flakes Buah Sukun dan Kacang Hijau

\begin{tabular}{lrrrr}
\hline \multirow{2}{*}{ Komposisi (g) } & \multicolumn{4}{c}{ Formula } \\
\cline { 2 - 5 } & F0 & F1 & F2 & F3 \\
\hline Jagung & 90 & 0 & 0 & 0 \\
Tapioka & 60 & 50 & 30 & 0 \\
Sukun & 0 & 50 & 60 & 100 \\
Kacang Hijau & 0 & 50 & 60 & 50 \\
Susu & 15 & 15 & 15 & 15 \\
Telur & 10 & 10 & 10 & 10 \\
Gula & 60 & 60 & 60 & 60 \\
Garam & 2 & 2 & 2 & 2 \\
\hline
\end{tabular}

Keterangan:

F0: jagung $90 \mathrm{~g}$, tapioka $60 \mathrm{~g}$, sukun $0 \mathrm{~g}$, kacang hijau $0 \mathrm{~g}$.

$\mathrm{F} 1$ : jagung $0 \mathrm{~g}$, tapioka $50 \mathrm{~g}$, sukun $50 \mathrm{~g}$, kacang hijau $50 \mathrm{~g}$

F2: jagung $0 \mathrm{~g}$, tapioka $30 \mathrm{~g}$, sukun $60 \mathrm{~g}$, kacang hijau $60 \mathrm{~g}$

F3: jagung $0 \mathrm{~g}$, tapioka $0 \mathrm{~g}$, sukun $100 \mathrm{~g}$, kacang hijau $50 \mathrm{~g}$

Sampel penelitian adalah flakes buah sukun dan kacang merah dengan formula flakes yang telah ditentukan. Ukuran sampel yang disajikan pada panelis adalah $5 \mathrm{~g}$ flakes ditambah $50 \mathrm{ml}$ susu cair untuk masing-masing formula flakes. Sampel diambil secara acak dari hasil pengulangan pada tiap perlakuan.

Panelis menilai sampel yang disajikan dengan nilai angket uji kesukaan meliputi warna, aroma, tekstur, dan rasa yaitu suka dan tidak suka (Soekarto,1985). Panelis pada penelitian ini adalah panelis anak yaitu anak kelas 2 sekolah dasar di MI Unggulan Sabilillah Lamongan sebanyak 34 orang. Bahan yang digunakan dalam pembuatan flakes buah sukun dan kacang hijau yaitu buah sukun, kacang hijau, jagung segar, tepung tapioka, telur ayam, susu bubuk full cream, margarin, gula pasir, dan garam. Formulasi flakes buah sukun dan kacang hijau pada penelitian ini disajikan pada Tabel 1.

Proses pembuatan flakes dimulai dengan pengupasan kulit sukun, mengecilkan ukuran, mengukus selama 20 menit untuk mendapatkan daging buah yang teksturnya padat dan mengurangi browning, selanjutnya menggiling sukun menjadi pasta. Perebusan kacang hijau kupas selama 5 menit dengan api kecil, meniriskan air pada rebusan kacang hijau dan menghaluskan kacang hijau. Mencampurkan telur dan margarin yang telah dicairkan dengan mixer sampai tercampur rata. Menambahkan pasta sukun, pasta kacang hijau, pasta jagung, tepung tapioka, gula, susu ke dalam adonan telur. Uleni adonan sampai tercampur rata. Pipihkan adonan dengan menggunakan roller dengan skala 5, lalu cetak adonan dengan cetakan kue. Tata adonan yang tercetak pada loyang kemudian panggang selama 30 menit dengan suhu $100^{\circ} \mathrm{C}$.

Penilaian yang dilakukan pada penelitian ini berupa penghitungan kadar protein dan penilaian daya terima. Penghitungan kadar protein dihitung berdasarkan TKPI (Tabel Komposisi Pangan Indonesia) 2009 sedangkan penilaian daya terima (warna, aroma, tekstur dan rasa) diperoleh dari penilaian panelis menggunakan angket uji kesukaan.

Setelah dilakukan penilaian daya terima berupa uji kesukaan dari seluruh formula flakes, data kesukaan flakes diolah kemudian formula flakes yang memiliki tingkat kesukaan paling tinggi di uji kembali kadar protein di laboratorium kimia dengan metode kjeldahl. Teknik analisis yang digunakan secara deskriptif menggunakan uji statistik chi square $\alpha=0,05$.

Penelitian ini melibatkan subjek manusia yaitu panelis untuk menilai daya terima produk. Penelitian ini telah mendapatkan persetujuan dari komisi etik penelitian kesehatan no: $365-$ KEPK Fakultas Kesehatan Masyarakat Universitas Airlangga Surabaya.

\section{HASIL DAN PEMBAHASAN}

Hasil uji daya terima panelis tak terlatih yaitu 34 siswa kelas 2 sekolah dasar terhadap tingkat

Tabel 2. Distribusi Tingkat Kesukaan Panelis terhadap Warna Flakes

\begin{tabular}{|c|c|c|c|c|c|c|c|}
\hline \multirow{2}{*}{ Formula } & \multicolumn{2}{|c|}{ Tidak Suka } & \multicolumn{2}{|c|}{ Suka } & \multicolumn{2}{|c|}{ Total } & \multirow{2}{*}{ Mean Rank } \\
\hline & n & $\%$ & $\mathrm{n}$ & $\%$ & $\mathbf{N}$ & $\%$ & \\
\hline F0 & 7 & 20,6 & 27 & 79,4 & 34 & 100 & $83,5^{\mathrm{a}}$ \\
\hline F1 & 10 & 29,4 & 24 & 70,6 & 34 & 100 & $77,5^{\mathrm{a}}$ \\
\hline F2 & 20 & 58,8 & 14 & 41,2 & 34 & 100 & $57,5^{\mathrm{b}}$ \\
\hline F3 & 21 & 61,7 & 13 & 38,3 & 34 & 100 & $55,5^{\mathrm{b}}$ \\
\hline
\end{tabular}

Notasi huruf $(\mathrm{a}, \mathrm{b})$ yang berbeda menunjukkan adanya perbedaan yang signifikan $(\alpha=0,05)$ 
Tabel 3. Distribusi Tingkat Kesukaan Panelis terhadap Aroma Flakes

\begin{tabular}{|c|c|c|c|c|c|c|c|}
\hline \multirow{2}{*}{ Formula } & \multicolumn{2}{|c|}{ Tidak Suka } & \multicolumn{2}{|c|}{ Suka } & \multicolumn{2}{|c|}{ Total } & \multirow{2}{*}{ Mean Rank } \\
\hline & $\mathbf{n}$ & $\%$ & $\mathbf{n}$ & $\%$ & $\mathbf{N}$ & $\%$ & \\
\hline Fo & 10 & 29,4 & 24 & 70,6 & 34 & 100 & $77,0^{\mathrm{a}}$ \\
\hline F1 & 5 & 14,7 & 29 & 85,3 & 34 & 100 & $87,0^{\mathrm{ab}}$ \\
\hline F2 & 17 & 50,0 & 17 & 50,0 & 34 & 100 & $63,0^{\mathrm{ac}}$ \\
\hline F3 & 25 & 73,5 & 9 & 26,5 & 34 & 100 & $47,0^{\mathrm{d}}$ \\
\hline
\end{tabular}

Notasi huruf (a, ab, ac, d) yang berbeda menunjukkan adanya perbedaan yang signifikan $(\alpha=0,05)$

kesukaan warna, aroma, tekstur, dan rasa flakes. Perlakuan yang diberikan pada setiap formula flakes adalah perbedaan jumlah buah sukun, kacang hijau, jagung, dan tepung tapioka sehingga mempengaruhi karakteristik flakes. Hasil uji daya terima karakteristik warna disajikan pada Tabel 2. Tabel 2 menunjukkan bahwa formula F0 dan F1 memiliki tingkat kesukaan yang sama yaitu $79,4 \%$ dari 34 panelis anak menyukai warna flakes. Warna pada F0 adalah kuning keemasan, F1 putih kecokelatan, walaupun berbeda warna keduanya cukup menarik dibandingkan dengan warna flakes F2 dan F3 yang memiliki warna lebih cokelat. Adanya warna cokelat tersebut dikarenakan adanya penambahan sukun dan kacang hijau. Pencokelatan enzimatis dikarenakan penambahan sukun yang merupakan buah yang mudah mengalami proses browning enzimatis karena mengandung enzim fenolase (Hartanti, 2013).

Pencoklatan juga disebabkan secara nonenzimatis yaitu adanya reaksi maillard pada saat proses pengolahan. Pada saat proses pemanggangan menimbulkan reaksi antara gula preduksi dengan asam amino yang berasal dari protein kacang hijau, susu dan telur sehingga terjadi perubahan warna cokelat bahan. Sejalan dengan pernyataan Kurniawati dan Ayustaningwarno (2012) bahwa reaksi millard yang terjadi antara gula pereduksi dengan asam amino yang menghasilkan warna kecokelatan pada bahan makanan ketika mengalami proses pemanasan.

Aroma produk dapat mempengaruhi penilaian kesukaan produk. Aroma merupakan rangsangan bau yang ditimbulkan oleh saraf olfaktori yang berbeda sari hidung ketika makanan masuk ke dalam mulut (Winarno, 2004). Hasil uji daya terima aroma flakes disajikan pada Tabel 3.

Tabel 3 menunjukkan daya terima aroma tertinggi adalah F1 $(85,3 \%)$ menyukai aroma flakes F1 Aroma yang ditimbulkan flakes F1 adalah aroma khas sukun yang tidak terlalu tajam dibandingkan F2 dan F3. Pada F1, aroma khas sukun tidak terlalu tajam, hal tersebut dikarenakan komposisi pasta sukun, kacang hijau, dan tepung tapioka memiliki proporsi yang seimbang serta adanya susu bubuk dapat menutupi aroma tajam dari sukun. Perbedaan aroma antar perlakuan tersebut dikarenakan subtitusi sukun, sedangkan subtitusi kacang hijau pada flakes tidak memiliki dampak negatif terhadap aroma flakes. Penelitian Yusufu (2015) mengenai pemanfaatan kacang hijau dalam pembuatan cookies menyatakan bahwa penambahan kacang hijau dalam pembuatan cookies meningkatkan daya terima cookies. Semakin tajam aroma sukun yang ditimbulkan semakin rendah daya terima aroma, sejalan dengan penelitian Sukandar, dkk., (2014) bahwa cookies sukun formula dasar memiliki daya terima aroma kurang baik yang menyebabkan

Tabel 4. Distribusi Tingkat Kesukaan Panelis terhadap Tekstur Flakes

\begin{tabular}{lccccccc}
\hline \multirow{2}{*}{ Formula } & \multicolumn{2}{c}{ Tidak Suka } & \multicolumn{2}{c}{ Suka } & \multicolumn{2}{c}{ Total } & \multirow{2}{*}{ Mean Rank } \\
\cline { 2 - 7 } & $\mathbf{n}$ & $\mathbf{\%}$ & $\mathbf{n}$ & $\mathbf{\%}$ & $\mathbf{N}$ & $\mathbf{\%}$ & \\
\hline F0 & 12 & 35,3 & 22 & 64,7 & 34 & 100 & $75,0^{\text {a }}$ \\
F1 & 2 & 5,9 & 32 & 94,1 & 34 & 100 & $95,0^{\mathrm{b}}$ \\
F2 & 24 & 70,6 & 10 & 29,4 & 34 & 100 & $51,0^{\text {c }}$ \\
F3 & 23 & 67,6 & 11 & 32,4 & 34 & 100 & $53,0^{\text {ac }}$ \\
\hline
\end{tabular}

Notasi huruf $\left({ }^{a, b, c, a c}\right)$ yang berbeda menunjukkan adanya perbedaan yang signifikan $(\alpha=0,05)$ 
kurang diterimanya cookies. Tekstur merupakan parameter yang penting dalam penerimaan produk pangan khususnya produk flakes. Tekstur pada produk flakes meliputi kerenyahan, kemudahan untuk dipatahkan dan konsistensi pada gigitan pertamanya (Fellows, 2000). Hasil uji daya terima tekstur flakes disajikan pada Tabel 4. Tabel 4 menunjukkan karakteristik tekstur tertinggi adalah flakes F1 (94,1\%) Panelis anak menyukai tekstur selanjutnya diikuti oleh F0 (64,7\%).

Tekstur flakes subtitusi buah sukun dan kacang hijau adalah renyah, kering, dan tidak mudah hancur namun tidak keras. Pada flakes modifikasi F1 yang memiliki komposisi buah sukun, kacang hijau dan tapioka memiliki tekstur yang paling renyah dibandingkan dengan F2 dan F3. Hal tersebut dikarenakan pada F1 terdapat tepung tapioka yang jumlahnya lebih banyak dari pada F2 dan F3, tepung tapioka pada pengolahan produk kering berfungsi sebagai perenyah karena kandungan amilopektin pada tapioka lebih besar dari sukun dan kacang hijau. Sehingga pengurangan proporsi tepung tapioka dalam pembuatan flakes akan menyebabkan tekstur flakes semakin keras. Sesuai dengan pernyataan Niken dan Adepristian (2013) bahwa amilopektin berfungsi memberikan sifat renyah dan garing pada crackers.

Rasa makanan merupakan atribut penilaian makanan yang melibatkan panca indra lidah. Pada flakes subtitusi buah sukun dan kacang hijau rasa dominan adalah manis. Hasil uji daya terima rasa flakes disajikan pada Tabel 5. Tabel 5 menunjukkan bahwa formula F1 memiliki penerimaan karakteristik rasa flakes tertinggi yaitu sebesar $91,2 \%$ diikuti oleh formula dasar F0 $85,3 \%$. Rasa flakes pada dasarnya adalah manis. Namun, seiring dengan subtitusi pasta buah sukun akan menimbulkan after taste pahit. Perubahan rasa pada produk subtitusi sukun terjadi pada produk kering seperti dalam penelitian Sukandar dkk. (2014) cookies sukun memiliki rasa yang khas, seperti rasa langu yang menyebabkan daya terima yang kurang oleh panelis. Hal yang serupa juga terjadi pada hasil penelitian Sitohang (2015) yang menunjukkan bahwa semakin tinggi perbandingan tepung sukun pada pembuatan cookies menyebabkan rasa pahit sehingga kurang disukai panelis. Rasa pahit tersebut disebabkan karena buah sukun mengandung komponen penyebab rasa pahit yaitu tanin, $\mathrm{HCN}$, dan asam fitat (Balitbangtan, 2015). Penelitian pada tepung biji sukun menunjukkan kandungan tanin sebesar $18,16 \mathrm{mg} / \mathrm{g}$ dan perlakuan pengolahan seperti perebusan dan germinasi dapat menurunkan kadar tanin (Ugwu, dkk., 2006).

Hasil uji daya terima flakes pada keseluruhan karakteristik yang disajikan pada Gambar 1 menunjukkan semakin tinggi subtitusi sukun dan kacang hijau maka semakin rendah daya terima flakes. Hal tersebut sejalan dengan penelitian Ojinnaka, dkk (2013) yang menyatakan bahwa peningkatan subtitusi sukun pada pengolahan cookies menyebabkan penurunan yang signifikan untuk mutu sensoris. Penilaian daya terima tertinggi secara keseluruhan karakteristik (warna, aroma, tekstur dan rasa) flakes adalah formula modifikasi $\mathrm{F} 1$, dengan proporsi yang seimbang antara buah sukun (50 g), kacang hijau (50 g) dan tepung tapioka $(50 \mathrm{~g})$.

Perbedaan perlakuan yang diberikan pada setiap formula yaitu jumlah pasta buah sukun, kacang hijau, dan tapioka sehingga berpengaruh pada karakteristik flakes.

Hasil analisis statistik chi square pada penilaian warna, aroma, tekstur, dan rasa didapatkan hasil terdapat perbedaan yang signifikan $(\alpha \leq 0,05)$ pada setiap karakteristik antara F0

Tabel 5. Distribusi Tingkat Kesukaan Panelis terhadap Rasa Flakes

\begin{tabular}{|c|c|c|c|c|c|c|c|}
\hline \multirow{2}{*}{ Formula } & \multicolumn{2}{|c|}{ Tidak Suka } & \multicolumn{2}{|c|}{ Suka } & \multicolumn{2}{|c|}{ Total } & \multirow{2}{*}{ Mean Rank } \\
\hline & $\mathbf{n}$ & $\%$ & $\mathbf{n}$ & $\%$ & $\mathbf{N}$ & $\%$ & \\
\hline F0 & 5 & 14,7 & 29 & 85,3 & 34 & 100 & $85,5^{a}$ \\
\hline F1 & 3 & 8,8 & 31 & 91,2 & 34 & 100 & $89,5^{\mathrm{a}}$ \\
\hline F2 & 21 & 61,8 & 13 & 38,2 & 34 & 100 & $55,5^{b}$ \\
\hline F3 & 26 & 76,5 & 8 & 23,5 & 34 & 100 & $43,5^{c}$ \\
\hline
\end{tabular}

Notasi huruf $\left({ }^{\mathrm{a}, \mathrm{b}, \mathrm{c}}\right)$ yang berbeda menunjukkan adanya perbedaan yang signifikan $(\alpha=0,05)$ 


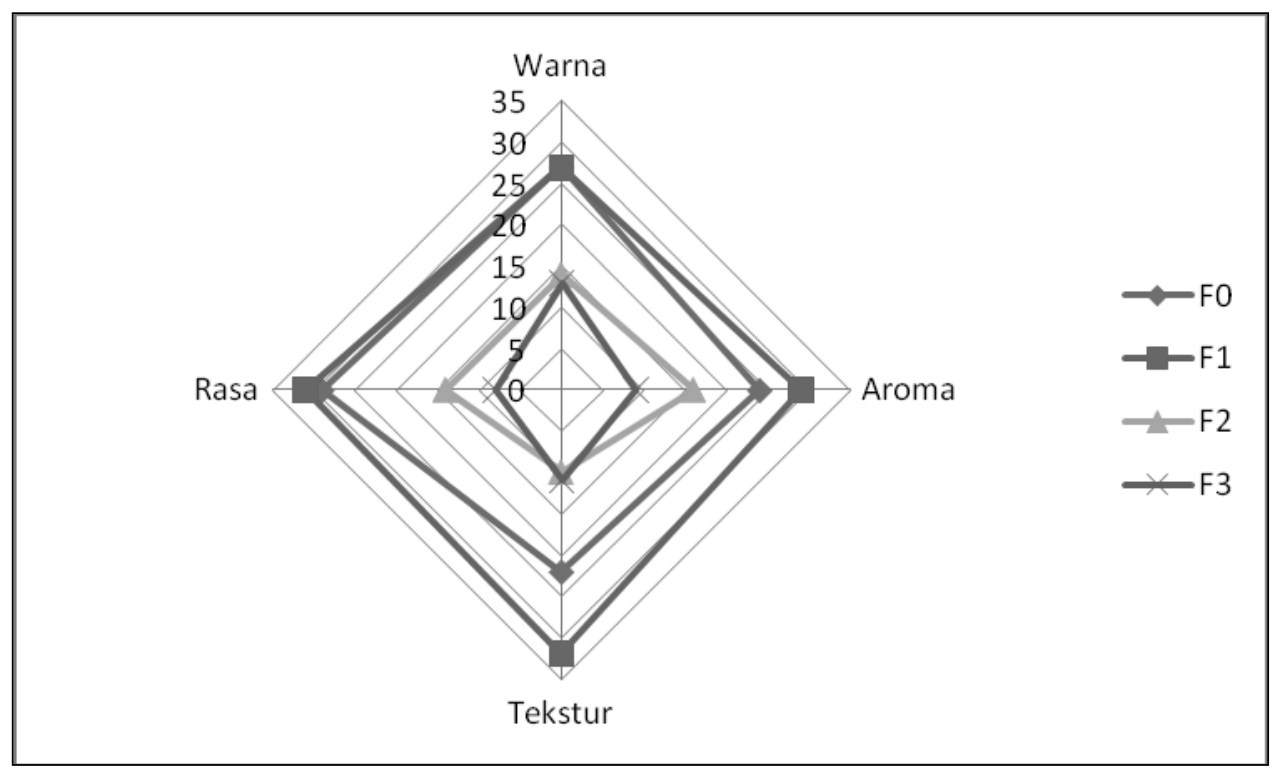

Gambar 1. Diagram Penilaian Keseluruhan Daya Terima Flakes.

dengan $\mathrm{F} 2$, F0 dengan $\mathrm{F} 3$, $\mathrm{F} 1$ dengan $\mathrm{F} 2$, dan $\mathrm{F} 1$ dengan F3, sedangkan tidak terdapat perbedaan yang signifikan $(\alpha \geq 0,05)$ terhadap daya terima warna, aroma, tekstur dan rasa flakes F0 dengan F1 dan F2 dengan F3.

Penilaian daya terima keseluruhan terhadap karakteristik warna, aroma, tekstur, dan rasa disajikan pada Gambar 1. Pada Gambar 1 terlihat bahwa formula F1 (buah sukun $50 \mathrm{~g}$, kacang hijau $50 \mathrm{~g}$, dan tepung tapioka $50 \mathrm{~g}$ ) memiliki penilaian tertinggi seluruh karakteristik penilaian uji kesukaan.

Selain daya terima yang baik, untuk dijadikan sebagai alternatif PMT-AS adalah mengandung protein minimal $5 \mathrm{~g}$ per porsi penyajian. Flakes subtitusi buah sukun dan kacang hijau merupakan produk alternatif PMT-AS yang tinggi protein. Kadar protein pada $100 \mathrm{~g}$ berdasarkan perhitungan TKPI (Tabel Komposisi Pangan Indonesia) 2009 disajikan pada Tabel 6.
Tabel 6 menunjukkan kandungan protein per $100 \mathrm{~g}$ flakes terendah adalah F0 (jagung $90 \mathrm{~g}$ dan tepung tapioka $60 \mathrm{~g}$ ) dan tertinggi adalah formula F2 (subtitusi buah sukun $60 \mathrm{~g}$, kacang hijau $60 \mathrm{~g}$, dan tapioka $30 \mathrm{~g}$ ). Namun dilihat dari semua flakes, subtitusi sukun dan kacang hijau (F1, F2, dan F3) telah memenuhi persyaratan PMT-AS yaitu mengandung protein minimal $5 \mathrm{~g}$ dan telah memenuhi kecukupan protein pada makanan kudapan (snack) menurut AKG harian anak usia sekolah yaitu $10-20 \%(4,9 \mathrm{~g}-9,8 \mathrm{~g})$. Hasil analisis laboratorium pada flakes formula F1 didapatkan nilai protein yang tidak berbeda jauh yaitu 9,2\% per $100 \mathrm{~g}$ flakes. Subtitusi kacang hijau pada pengolahan flakes mampu meningkatkan kandungan proteinnya. Pada F0 kandungan protein flakes 4,9 g menjadi 8,9 g pada F1 dan terus meningkat seiring dengan penambahan subtitusi kacang hijau. Peningkatan protein tersebut sejalan dengan Azizah, dkk. (2012) bahwa

Tabel 6. Distribusi Kadar Protein per 100 g Flakes

\begin{tabular}{lcc}
\hline & Formula & \multicolumn{2}{c}{ Kadar Protein (g) } \\
\cline { 2 - 3 } & TKPI & Laboratorium \\
\hline F0 & 4,3 & - \\
F1 & 8,9 & 9,2 \\
F2 & 10,1 & - \\
F3 & 9,1 & - \\
\hline
\end{tabular}

-) tidak dianalisis laboratorium 
Tabel 7. Kontribusi Flakes dengan Susu terhadap Standar Produk PMT-AS dan AKG Anak Sekolah (7-9 tahun)

\begin{tabular}{lccccc}
\hline Kandungan Gizi & Flakes + Susu & $\begin{array}{c}\text { Kecukupan } \\
\text { AKG }\end{array}$ & $\begin{array}{c}\text { Standar Produk } \\
\text { PMT-AS }\end{array}$ & $\begin{array}{c}\text { Kons. AKG } \\
\text { (\%) }\end{array}$ & $\begin{array}{c}\text { Kons. Produk PMT } \\
\text { (\%) }\end{array}$ \\
\hline Energi (Kal) & 300,5 & 1850 & 300 & 16,2 & 100 \\
Protein $(\mathrm{g})$ & 9,8 & 49 & 5 & 20,0 & 196 \\
\hline
\end{tabular}

subtitusi kacang hijau terhadap tepung terigu pada pembuatan cookies tidak berpengaruh terhadap fungsi makanan tetapi meningkatkan kandungan protein cookies.

Flakes subtitusi pasta buah sukun dan kacang hijau dibuat untuk dijadikan alternatif produk PMT-AS yang bertujuan untuk mempromosikan program disversifikasi pangan sejak usia dini. Sukun merupakan bahan makanan pokok alternatif beras, selain kandungan karbohidrat yang tinggi sebagai sumber energi, kandungan vitamin dan mineral sukun lebih besar dari pada beras (PERSAGI, 2009). Namun kandungan protein pada sukun rendah, sehingga perlu didiversifikasikan bahan lain sumber protein yaitu kacang hijau untuk memperoleh produk flakes yang berkualitas.

Penambahan protein pada kacang hijau memberikan pengaruh dalam penambahan gizi pada sukun yang memiliki kandungan protein hanya $2,06 \%$ per 100 gram (Adinugraha, dkk., 2013). Protein pada kacang hijau merupakan protein nabati sebesar 27,6 g/100 g kacang hijau (Oburuoga, dkk., 2012). Protein pada kacang hijau kaya asam amino leusin, arginin, isoleusin, valin, dan lisin (Astawan, 2009). Arginin merupakan asam amino yang dapat mengaktifkan hormon pertumbuhan (Human Growth Hormon) dan bertanggung jawab untuk meningkatkan pertumbuhan otot, membakar lemak serta mengatur sistem imun (Fernandez, 2014).

Pengolahan sukun dan kacang hijau dalam bentuk flakes merupakan upaya diversifikasi bahan pangan lokal untuk upaya perbaikan gizi pada anak usia sekolah. Upaya perbaikan gizi tersebut dikenal dengan program PMT-AS. Menurut penelitian yang dilakukan oleh Tanziha (2013) di SDN Pasanggrahan 2 Purwakarta yaitu pemberian makanan kudapan untuk anak sekolah seperti getuk singkong, bubur lemu, pisang goreng, bubur kacang hijau dan lainnya selama 6 bulan menunjukkan adanya perbaikan status gizi dari sebelum intervensi $52,5 \%$ menjadi $92,1 \%$ setelah intervensi. Kudapan tersebut mengandung $300 \mathrm{Kal}$ dan $7 \mathrm{~g}$ protein.

Pada umumnya, konsumsi flakes adalah dengan menambahkan susu, dengan asumsi jumlah flakes sebanyak $45 \mathrm{~g}$ dan ditambahkan susu bubuk instan sebanyak $27 \mathrm{~g}$ sehingga diketahui persentase pemenuhan zat gizi per takaran saji flakes dengan susu terhadap persyaratan kandungan gizi PMT-AS dan AKG anak sekolah (7-9 tahun). Kontribusi flakes ditambah susu terhadap standar produk PMT-AS dan AKG anak sekolah disajikan pada tabel 7.

Tabel 7 menunjukkan bahwa per porsi sajian flakes (45 g) yang ditambahkan dengan susu bubuk (27 g) telah memenuhi AKG (10-20\%) anak usia sekolah yaitu $16,2 \%$ pemenuhan energi harian dan $20 \%$ pemenuhan protein harian serta telah memenuhi standar produk PMT-AS yaitu minimal mengandung $300 \mathrm{kal}$ energi dan $5 \mathrm{~g}$ protein per porsi sajian.

Subtitusi buah sukun dan kacang hijau pada produk flakes sebagai alternatif PMT anak sekolah yang cukup energi tinggi protein didukung oleh penelitian Abiodun, dkk. (2001) bahwa pemberian pasta sukun yang kaya gizi, mudah didapatkan dan mudah diterima anak bisa dijadikan sebagai makanan alternatif perbaikan gizi anak gizi kurang (KEP). Sedangkan subtitusi kacang hijau pada flakes ditujukan untuk meningkatkan kandungan protein flakes. Menurut Pasha, dkk. (2011) tentang pemanfaatan tepung kacang hijau yang tinggi protein pada produk sereal yang banyak diminati masyarakat sehingga dapat dijadikan alternatif mengatasi masalah kekurangan protein akibat kelaparan.

\section{KESIMPULAN DAN SARAN}

Penilaian daya terima pada karakteristik warna, aroma, tekstur, dan rasa secara keseluruhan tertinggi adalah $\mathrm{F} 1$ (buah sukun $50 \mathrm{~g}$, kacang hijau $50 \mathrm{~g}$ dan tepung tapioka $50 \mathrm{~g}$ ). Kandungan 
protein flakes $\mathrm{F} 1$ per $100 \mathrm{~g}$ adalah $9,2 \mathrm{~g}$ dan kandungan per sajian flakes (45 g) ditambahkan susu (27 g) adalag 9,8 g. Kandungan protein flakes F1 telah memenuhi $20 \%$ AKG anak usia sekolah dan memenuhi persyaratan produk PMT-AS yaitu minimal $5 \mathrm{~g} / \mathrm{sajian}$. Formula dengan komposisi terbaik berdasarkan daya terima dan kandungan protein adalah $\mathrm{F} 1$ yaitu $50 \mathrm{~g}$ pasta buah sukun, pasta $50 \mathrm{~g}$ kacang hijau dan $50 \mathrm{~g}$ tepung tapioka.

Flakes sukun dan kacang hijau layak dijadikan alternatif PMT-AS karena telah memenuhi persyaratan produk PMT-AS yaitu mengandung protein minimal $5 \mathrm{~g}$ per sajian.

\section{DAFTAR PUSTAKA}

Abiodun, I.R., Olowu, A.O, Olanrewaju,D.M. \& Akesode, F.A. (2001). Efficacy of african breadfruit (Treculia Africana) in the nutritional rehabilitation of children with protein-energy malnutrition. Nigerian journal of paediatric 28 (4): 128-134. Diakses dari http://www.ajol.info/ index.php/njp/article/viewFile/12067/15152

Adinugraha, H.A. \& Kartikawati,N.K. (2012). Variasi Morfologi dan Kandungan Gizi Buah Sukun. Jurnal Wana Benih Vol. 13 No. 2, 96-106. Diakses dari http://www.biotifor.or.id

Astawan, M. (2009). Sehat dengan kacang dan biji-bijian. Jakarta: Penebar Swadaya.

Azizah, N., A.,M.Azizah, L-H.,Ho. (2012). Physicochemical and organoleptic properties of cookies incorporated with legume flour. International Food Research Journal 19(4), 1539-1543. Diakses dari: http://www.ifrj.upm. edu.my

Balitbangtan. (2015). Tepung Sukun Mutu Premium. Jakarta: Badan Penelitian dan Pengembangan Pertanian.

De Onis M., Blossner M., \& Borghi E. (2011). Prevalence and trends of stunting among preschool children, 1990-2020. Public Health Nutr, (4): 1-7. Diakses dari http://www.who.int/ nutgrowthhdb/publications/Stunting1990_2011. pdf

Fellows, P. (2000). Woodhead Publishing Limited. Cambridge England, Food Processing Technology Principles and Practice, Second Edition. Diakses dari http://www.webpal.org/ SAFE/aaarecovery/2_food_storage/Food $\% 20$ Processing\%20Technology.pdf
Fernandez, I. (2014). Asam amino esensial untuk tumbuh kembang anak. Semarang: Food for Kids Indonesia edisi 11 bulan November.

Hartanti, F.D., Amanto, B.S., \& M. Dimas, R.A. (2013). Kajian Karakteristik Fisikokimia Tepung Sukun (Artocarpus communis) Termodifikasi dengan Variasi Konsentrasi dan Lama Perendaman Asam Laktat. Jurnal Teknosains Pangan, Vol. 2 No. 4. Diakses dari http://ilmupangan.fp.uns.ac.id

Kementerian Dalam Negeri. (2011). Peraturan Menteri Dalam Negeri Nomor 18 tentang Pedoman Penyediaan Makanan Tambahan Anak Sekolah Tahun 2011. Jakarta : Kementerian Dalam negeri.

Kementerian Pertanian. (2014). Statistik Produksi Hortikultura Tahun 2013. Jakarta: Direktorat Jendral Hortikultura, Kementerian Pertanian.

Kurniawati \& Ayustaningwarno. (2012). Pengaruh subtitusi tepung terigu dengan tepung tempe dan tepung ubi jalar terhadap kadar protein, kadar b-karoten dan mutu organoleptik roti manis. Journal of Nutrition College, 1(1), 344-351. Diakses dari http://ejournal-s1.undip.ac.id/ index.php/jnc

Marsaoly,M., Bahar,B. \& Sirajuddin. (2011). Pengaruh pemberian makanan tambahan (Telur rebus dan bubur kacang hijau) terhadap status gizi anak usia sekolah. Jurnal Media Gizi Indonesia, Vol. 1 No. 1: 14-20. Diakses di download.portalgaruda.org

Niken, AH. \& Adepristian DY. (2013) Isolasi Amilosa dan Amilopektin dariPati kentang. Jurnal Teknologi Kimia dan Industri, 2(3). 57-62. Diakses dari http://ejournal-s1.undip. ac.id/index.php/jkti

Oburuoga, A.C. \& Anyika, J.U. (2012). Nutrient and antinutrient composition of mungbean (vigna radiata), Acha (Digitaria exilis) and Crayfish (Astacus fluvitalis) flours. Pakistan Journal of Nutrition, 11(9): 841-844. Diakses di www.pbjs.org

Ojinnaka, M.C., Anyanwu, F.A. \& Ihemeje, A. (2013). Nutritional of cookies produced from african breadfruit (treculia africana) strach wheat flour. International Journal of Agricultural and Food Science, Vol. 3 No. 3: 95-99. Diakses dari http://urpjournals.com/ tocjnls/7_13v3i3_4.pdf

Pasha, I., Rashid, S., Anjum, F.M. \& Sulthan, M.T. (2011). Quality Evaluation of Wheat- 
Mungbean flour blends and their utilization in baked products. Pakistan Journal of Nutrition, 10(4): 388-392. Diakses dari:http://www.pjbs. org/pjnonline/fin1947.pdf

Persatuan Ahli Gizi Indonesia (PERSAGI). (2009). Tabel Komposisi Pangan Indonesia. Surabaya: DPD Persagi Jawa Timur.

Sitohang, K.A.K., Lubis, Z. \& Lubis, L.M. (2015). Pengaruh perbandingan jumlah tepung terigu dan tepung sukun dengan jenis penstabil terhadap mutu cookies sukun. Jurnal Rekayasa Pangan dan Pertanian, Vol. 3 No. 3. Diakses dari http://download.portal garuda.org

Soekarto S.T. (1985). Penilaian Organoleptik untuk Industri Pangan dan Hasil Pertanian. Jakarta: Bhratara Karya Aksara.

Sukandar, D., Muawanah,A., Amelia,E.R. \& Basalamah, W. (2014). Karakteristik Cookies Berbahan Dasar Tepung Sukun (Artocarpus communis) bagi Anak Penderita Autis. Jurnal Valensi, Vol. 4 No. 1: 13-15. Diakses dari http://journal.uinjkt.ac.id/valensi/article/ viewFile/1047/930

Syatyawati, R. (2013). Hubungan antara Status Gizi dengan Prestasi Belajar Anak Sekolah Dasar di Desa Grenggeng Kecamatan Karanganyar Kebumen (Skripsi, Universitas Muhammadiyah Surakarta, Surakarta). Diakses dari http://eprints. ums.ac.id/2354/12/NASKAH_PUBLIKASI. pdf

Tanziha, I., Rahmawati, I., Maharani \& Rusmawati, D. (2013). Pengaruh pemberian kudapan terhadap status gizi dan status anemia siswa SDN Pasanggrahan 2 Purwakarta. Jurnal Ekologi, Vol. 13, No. 1: 24-32. Diakses dari www.unpak.ac.id

Ugwu, F.M. \& Oranye N.A. (2006). Effect of some processing methods on the toxic components of Africa breadfruit (Treculia Africana) African. Journal of Biotecnology, Vol. 5 No. 22: 2329-2333. Diakses dari http:// www.academicjournals.org/journal/AJB/ article-full-text-pdf/

Valentina, V., Palupi, N.S. \& Andarwulan, N. (2014). Asupan Kalsium dan Vitamin D pada Anak Indonesia 2-12 Tahun. Jurnal Teknologi dan Industri Pangan, 25(1). Diakses dari http:// journal.ipb.ac.id/index.php/jti

Winarno. (2004). Kimia pangan dan gizi. Jakarta: Gramedia Pustaka Utama.

Yusufu, M.I., Obiegbuna, J.E. \& Yusufu, P.A. (2015). Studies on the utillization of green bean as raw material in cookies produced from wheat flour. Agricultural Science Research Journal, 5(6): 92-97. Diakses dari http:/www. Resjournals.com/ARJ

Koswara, S. (2006). Sukun sebagai Cadangan Pangan Alternatif. Diakses dari ebookpangan. com.

Widyasitoresmi, H.S. (2010). Formulasi dan Karakterisasi Flake Berbasis Sorgum (Sorghum Bicolor L.) dan Ubi Jalar Ungu (Ipomoea Batatas L.). (Skripsi, Institut Pertanian Bogor, Bogor). Diakses dari http://repository.ipb.ac.id 